\title{
The Effect of Learning Style on the Performance of Students in a Preemptive Focus-on-Form Instruction
}

\author{
NASRIN KHAKI \\ Payame Noor University, Sari, Iran \\ MAHYAR GANJABI \\ Payame Noor University, Tehran, Iran \\ ABolfazl KhODAMORAdi \\ Office of Education, Mahallat, Markazi, Iran
}

Received: 31 January 2014 / Accepted: 15 November 2014

ISSN: 1697-7467

\begin{abstract}
Due to the crucial role of learning styles in language learning, this study aimed at investigating whether different learning styles play a role in a grammar classroom taught based on a preemptive focus-on-form instruction. To fulfill this objective, 65 female students studying in a state pre-university center were selected as the sample of the study. After determining their learning styles based on Paragon Learning Style Inventory, all of them were taught a grammatical structure based on focus-on-form instruction. The results of the study revealed that the difference in the participants' language performance due to the effect of their learning styles and focus-on-form instruction they received was not statistically significant.
\end{abstract}

Key words: focus-on-forms, preemptive focus-on-form, learning style, grammar teaching

El efecto del estilo de aprendizaje en el rendimiento de estudiantes en una instruccion que previene el enfoque-en-la-forma

RESUMEN: Debido al papel crucial de los estilos de aprendizaje en el aprendizaje de idiomas, este estudio se propuso investigar si los diferentes estilos de aprendizaje juegan un papel en clases de gramática enseñada con base en una instrucción que prevenga el enfoque-enla-forma. Para alcanzar este objetivo, 65 alumnas que estudian en un centro pre-universitario estatal participaron en este estudio. Después de determinar sus estilos de aprendizaje basados en Paragon Learning Style Inventory, a todas ellas se les enseñó una estructura gramatical basada en la instrucción enfocada-en-la-forma. Los resultados del estudio revelaron que no existen diferencias significativas en el rendimiento del idioma de los participantes debido al efecto de los diferentes estilos de aprendizaje y una enseñanza enfocada-en-la-forma.

Palabras clave: enfoque en las formas, el enfoque preventivo en la forma, estilo de aprendizaje, enseñanza de la gramática

\section{INTRODUCTION}

Over the last two decades, research has indicated that second language (L2) learners studying in language immersion classrooms develop high levels of comprehension skills, extensive fluency, and self-confidence in L2 production, yet they experience a permanent 
difficulty in grammatical development (Harley, Cummins, Swain, and Allen, 1990). On the other hand, it has been found that teaching grammar in an isolated manner is insufficient to promote language acquisition (Long, 1991; Long and Robinson, 1998). Ellis (2001) and Doughty and Williams (1998a) assert that one solution to this problem is convincing students to focus on the target forms by helping them to notice the new forms in the input. Another solution proposed by Swain (2005) is that teachers should provide learners with opportunities in which they can utter output containing that special target form. In this way, learners are helped to notice the gap between their current ability and the correct use of the given form.

Numerous researchers have worked on the effects of learning styles and the focus-on-form instruction on learning an L2 (Barkhuizen, 1998; Basturkmen, and Loewen, 2001a; Doughty, 2001; Doughty and Williams, 1998b; Ellis, Long and Robinson, 1998; Kavaliauskiene, 2003; Reid, 1987). However, as Doughty (2005) points out, individual variation shown by participants as the effect of instruction may have been due to the individual differences, or the mismatches between cognitive and instructional styles, and such differences have not been routinely taken into account in instructed second language acquisition (SLA) studies. Poole (2005) asserts that almost no study supporting focus-on-form instruction has been conducted in developing countries. Therefore, instructors and curriculum designers do not have enough information to judge whether focus-on-form instruction can be appropriate in their programs or not. Since the effects of factors such as individual differences have not been studied in a focus-on-form instruction, the researchers are going to investigate if learning styles actually play a role in L2 learning in a situation where focus-on-form instruction is used. If yes, then how different learning styles, namely, extrovert-introvert, sensate-intuitive, feeler-thinker, and judger-perceiver, influence the performance of language learners.

\section{Literature ReView}

\subsection{Learning styles}

Recently, there has been a shift to learner-oriented approaches in language pedagogy. Consequently, it is of crucial importance to understand learners' learning preferences. For example, some learners like to learn individually, while others prefer interacting with their peers when learning something. Moreover, learning is usually affected by learning styles and, if learners employ multiple learning styles, learning rate is higher (Reid, 1987).

As Celce-Murcia (2001) and Reid (1987) state, learning styles are the different ways of taking in and processing information by the learner. Kolb and Kolb (2005) assert that learning style describes the differences in the way learners prefer employing in the learning cycle. They believe that in selecting a particular way of learning, we are normally affected by features such as life experiences and demands of the present environment. Therefore, a teacher should determine his/her students' learning styles and provide teaching interventions that are attuned with the learners' learning style in order to achieve a desired learning outcome. Reid (1995) divides learning styles into three major categories: Cognitive learning, sensory learning, and personality learning styles. This study was concerned with 8 types of personality learning styles including:

a. Extrovert vs. introvert: Extroverts are those who are interested in having contact with the outside world and relationship with others, while introverts are more interested in individual situation. 
b. Sensate vs. intuitive: Sensate learners are those who learn better when they experience something with their five senses. On the other hand, intuitive learners learn best when they find the relationships among things.

c. Thinker vs. feeler: The former learns from impersonal circumstances and logical consequences, whereas the latter prefers personalized circumstances and social values.

d. Judger vs. perceiver: Judgers learn by reflection and analysis; while perceivers learn through feeling and negotiation.

Studies related to cognitive and learning styles in the field of SLA have been a motivating puzzle for a long time and quite a lot of studies have been conducted in this area (Dörnyei and Skehan, 2005). Since the learning styles play a crucial role in the learning process, educators cannot neglect them. Once teachers become aware that different students learn differently, they will determine students' learning styles and accommodate them. According to Felder (1996), how much students learn in the class is determined partially by the students' ability and prior preparation, and mainly by their learning style and teachers' teaching style.

\subsection{Focus on form}

Teaching linguistic forms, especially grammar, still has a major place in language pedagogy. It is possible for learners to acquire linguistic forms without instruction, although they cannot usually achieve a high level of linguist competence through focus on meaning instruction per se (Ellis et al., 2002). Due to the extensive attention to teaching grammar for communicative purposes, the procedures for achieving this deserve careful consideration. Actually in focus-on-form instruction, the primary focus of attention is on meaning and research studies have shown that noticing has a fundamental role in learning an L2 (Leow, 2002, 1997; Robinson, 1995; Schmidt, 1993, 1990; Sharwood Smith, 1993, 1981; Tomlin and Villa, 1994; Wong, 2001). While Long (1991) believes that focus-on-form instruction involves drawing the learner's attention to linguistic forms "as they arise incidentally in lessons whose overriding focus is on meaning or communication" (p.41), Ellis (2001) defines it as "any planned or incidental instructional activity that is intended to induce language learners to pay attention to linguistic form" (p. 1-2).

There are different taxonomies used for focus-on-form instruction, one is the distinction made between reactive and preemptive focus-on-form. Reactive focus-on-form occurs when the teacher reacts to a perceived problem while doing a communicative task, whereas preemptive focus-on-form involves spending some time out of the communicative task to pay attention to a linguistic form when no actual problem in production has arisen (Ellis, 2001; Ellis et al., 2002). Ellis et al. (2002) continue that preemptive focus-on-form can be conversational (during the communicative activity) or didactic (i.e. participants take timeout from communicating and discuss the linguistic form). Another feature of preemptive focus-on-form is that it may be learner- or teacher-initiated. Generally, learners rarely initiate focus-on-form (Williams, 1999). Moreover, Ellis et al. (2002) believe that what is a gap for one learner may not be for others. However, Slimani (1989) found that learners reported a higher level of learning when they were the initiators. Of course, a teacher-initiated situation has its own problem, i.e. they interrupt the flow of the communication activity, yet an experienced teacher knows how to do it (Ellis et al., 2001b) 
The rationale for choosing preemptive focus-on-form in conducting this study is that it provides intensive coverage of one specific linguistic item (Doughty and Varela, 1998; Lyster, 2004). As mentioned before, preemptive focus-on-form can be of two kinds: studentand teacher-initiated (Ellis et al., 2002). In this study the latter was applied in which the teacher posed a linguistic form assumed to be problematic. On the other hand, some studies have indicated that while doing a meaning-focused activity, learners may benefit if they pay attention to form to promote their comprehension (Ellis, Basturkmen, and Loewen, 2001a; Lyster and Mori, 2006). Nassaji and Fotos (2007) have also concluded that meaningful activities, particularly those activities that involve production, must be amalgamated with formfocused activities so that we can develop the accuracy and fluency in learners. Furthermore, the pushed output hypothesis claims that when learners are involved in language production, their language knowledge improves (Swain and Lapkin, 1995). Moreover, Deykeyser et al. (2002) suggested that treatments that are based on production promote learners abilities on the uses of Spanish subjunctive, acquisition of Spanish copulas, acquisition of French causative, and the production of future tense in Italian. Therefore, based on the aforementioned studies, the researchers designed the activities in which students were encouraged to produce the grammatical structure.

\section{Research Questions}

In order to investigate the role of the four pairs of learning styles, the following research questions were formulated:

1. Does being introvert/extrovert play a role in learners' performance in a focus-on-form instruction?

2. Does being sensing/intuitive play a role in learners' performance in a focus-on-form instruction?

3. Does being thinker/feeler play a role in learners' performance in a focus-on-form instruction?

4. Does being judger/perceiver play a role in learners' performance in a focus-on-form instruction?

\section{Methodology}

\subsection{Participants}

The participants in this study were 65 Iranian female students, ranged in age from 17 to 19 (average: $18 \pm 0.54$ ). They attended three intact classes at a state pre-university center and had English for four hours a week as a part of their curriculum.

\subsection{Instrumentation}

The following materials were used in the study:

Pre-test: First of all, test 250B from Nelson (Flower and Coe, 1976) was selected to be administered, so as to have information about the students' proficiency level. 
Learning style inventory: To distinguish the participants' learning styles, Paragon Learning Style Inventory (PLSI) was employed. Revised in 1992, it is a 48-item learning style inventory that obtains a measure of the four psychological/learning dimensions, namely, extrovert-introvert, sensate-intuitive, feeler-thinker, and judger-perceiver. Based on the information in the site (www. Oswego.edu/plsi/), this inventory can be used for ages of 8 and older. It has been analyzed for its reliability and construct validity and the results have indicated that it has 60\%-70\% stability, like MBTI (Meyer-Briggs Type Indicator). Moreover, questions related to each pair of learning style act independently; in essence, the PLSI contains four separate inventories.

Post-test: A 25 -item test containing questions related to expressing purpose (15 items) and the previously taught structures (10 items), used as distracters, was designed, and administered for the post-test.

\subsection{Procedure}

To accomplish the study, the researchers applied explicit preemptive focus-on-form in this study. The grammatical structure selected for this study was 'expressing purpose' which was supposed to be taught in two sessions (each 90 minutes). Thus, the inventory was translated into Farsi by the researchers and then the translated inventory was revised by an English-to-Persian translation expert.

First, a standard test from Nelson was administered in all three classes. In the next session, the learning style questionnaire was filled out by the participants. Then, the data obtained from the pretest and the learning style inventory were fed into SPSS software (version 18) for analysis.

In order to direct the learners' attention to the grammatical point being taught, input enhancement was used and the structures in the passage were underlined (Fotos, 1993 and 1994; White, 1998; Williams and Evans, 1998). In the third session when the passage was being read in the class, the teacher posed some questions whose answers were stated in the underlined parts and the participants had to read them aloud. Then, with the help of the teacher they discussed the sentences to find out the different structures used for expressing purpose (infinitive to, in order to, so as to, and so that). At this stage, the participants got familiar with the structure of expressing purpose.

As mentioned before, Swain (2005) puts emphasis on the significance of production to develop the learner's awareness of the gap between what $\mathrm{s} /$ he knows and what really exists in target language. Thus, based on Output Hypothesis posed by Swain, two activities (a gap filling and a sentence completion activity) were designed to allow the learners to produce what is learnt in small groups in the fourth session. When each group finished doing the exercise, the teacher went to that group and corrected the errors with their own help. The error corrections were mainly repetition and recasting techniques. Then, in the last session the post-test was administered to see the role of their learning styles in their performance.

\subsection{Data analysis}

The data obtained from pretest, learning style inventory, and the post-test were all fed into the SPSS software (version 18). Since the score for the posttest designed by the researchers was 15 , the pretest score which was 50 was calculated based on 15 , as well. 
Then, the data for learning style was fed as nominal data, e.g. either introvert or extrovert, for each participant. The result of a descriptive analysis of the learning style variable was as follows: out of the 65 participants, 39 were introverts and 26 extroverts; 42 sensates and 23 intuitives; 23 feelers and 42 thinkers; and interestingly, 65 judgers and no perceivers. Since all the participants attending in this study were judgers, the $4^{\text {th }}$ question which was about the role of being judger/perceiver in the performance of the students in a focus-onform teaching setting could not be answered and was deleted from the research questions. In order to probe the research questions, an independent t-test was employed.

\section{RESULTS}

The total mean for pretest score was $5.34 \pm 2.01$ and for the post-test was $10.45 \pm 3.79$. Then three independent t-tests were applied between the three groups to find out whether there were any significant differences between each pair, the result of which are presented in Table 1.

Table 1. Independent T-Test for Pretest Scores of Different Learning Styles.

\begin{tabular}{|c|c|c|c|c|c|c|c|}
\hline & mean & SD & SEM & t-observed & df & t-critical & $\begin{array}{c}\text { Sig. } \\
\text { (2-tailed) }\end{array}$ \\
\hline $\begin{array}{l}\text { Introvert } \\
\text { extrovert }\end{array}$ & $\begin{array}{l}5.147 \\
5.587\end{array}$ & $\begin{array}{l}2.037 \\
2.022\end{array}$ & $\begin{array}{l}.467 \\
.505\end{array}$ & -.639 & 63 & 2.021 & .527 \\
\hline $\begin{array}{l}\text { Sensate } \\
\text { intuitive }\end{array}$ & $\begin{array}{l}5.072 \\
5.815\end{array}$ & $\begin{array}{l}2.015 \\
1.999\end{array}$ & $\begin{array}{l}.429 \\
.554\end{array}$ & -1.056 & 63 & 2.021 & .298 \\
\hline $\begin{array}{l}\text { Feeler } \\
\text { thinker }\end{array}$ & $\begin{array}{l}4.777 \\
5.686\end{array}$ & $\begin{array}{l}1.215 \\
2.322\end{array}$ & $\begin{array}{l}.337 \\
.495\end{array}$ & -1.305 & 63 & 2.021 & .201 \\
\hline
\end{tabular}

As the above table shows, there is no significant difference between the two levels of each group and the t-observed for introvert/extrovert students is much smaller than t-critical $\left(\mathrm{t}_{\text {observed }}=-0.63, \mathrm{t}_{\text {critical }}=2.02, \mathrm{p}>.05\right)$. Similar results were also observed for sensate/intuitive students $\left(\mathrm{t}_{\text {observed }}=-1.05, \mathrm{t}_{\text {critical }}=2.02, \mathrm{p}>.05\right)$ and for feeler/thinker students $\left(\mathrm{t}_{\text {observed }}=-1.30\right.$, $\left.\mathrm{t}_{\text {critical }}=2.02, \mathrm{p}>.05\right)$. Thus, it can be concluded that prior to the instruction, the participants of each pair had similar background knowledge.

To investigate the first research question (i.e. the role of introvert/extrovert style in the performance of students in a focus-on-form instruction), an independent t-test was used (See Table 2). 
Nasrin Khaki, Mahyar-Ganjabi and Abolfazl Khodamoradi The Effect of Learning Style...

Table 2. Independent T-Test for Posttest Scores of Introvert/Extrovert Students.

\begin{tabular}{|l|c|c|c|c|c|c|c|}
\hline & mean & SD & SEM & t-observed & df & t-critical & $\begin{array}{c}\text { Sig. } \\
\text { (2-tailed) }\end{array}$ \\
\hline Introvert & 9.631 & 3.876 & .889 & -1.422 & 63 & 2.021 & .164 \\
extrovert & 11.437 & 3.577 & .894 & & & \\
\hline
\end{tabular}

As Table 2 shows, the t-observed is much smaller that the $\mathrm{t}$-critical $\left(\mathrm{t}_{\text {observed }}=-1.42\right.$, $\left.\mathrm{t}_{\text {critical }}=2.02, \mathrm{p}>.05\right)$. Although there is a minute difference between the two means and the extroverts performed better after the instruction, the difference is not statistically meaningful $\left(\mathrm{t}_{63}=.16, \mathrm{p}>.05\right)$.

To answer the second research question which was whether being sensate/intuitive plays a role in the performance of students in a focus-on-form instruction; another independent t-test was run (See Table 3). The descriptive statistics showed that the sensates performed slightly better than the intuitives after being instructed $\left(\bar{x}_{\text {senates }}=10.81, \bar{x}_{\text {intuitives }}=9.84\right)$. The $\mathrm{t}$-test analysis revealed that the difference between the two groups was not statistically significant $\left(\mathrm{t}_{63}=.47, \mathrm{p}>.05\right)$.

Table 3: Independent T-Test for Posttest Scores of Sensate/Intuitive Students.

\begin{tabular}{|l|c|c|c|c|c|c|c|}
\hline & mean & SD & SEM & t-observed & df & t-critical & $\begin{array}{c}\text { Sig. } \\
\text { (2-tailed) }\end{array}$ \\
\hline Sensate & 10.818 & 3.825 & .815 & .726 & 63 & 2.021 & .473 \\
Intuitive & 9.846 & 3.826 & 1.061 & & & \\
\hline
\end{tabular}

The third research question dealt with whether being thinker/feeler plays a role in the performance of students in a focus-on-form instruction. Table 4 shows the mean differences for the feeler and thinker students $\left(\overline{\mathrm{x}}_{\text {feelers }}=11.53, \overline{\mathrm{x}}_{\text {thinkers }}=9.81\right)$. Similar to the previous research question, the independent t-test result did not show any significant difference between the two groups $\left(\mathrm{t}_{63}=.2, \mathrm{p}>.05\right)$.

Table 4: Independent T-Test for Posttest Scores of Feeler/Thinker Students.

\begin{tabular}{|l|c|c|c|c|c|c|c|}
\hline & Mean & SD & SEM & t-observed & df & t-critical & $\begin{array}{c}\text { Sig. } \\
\text { (2-tailed) }\end{array}$ \\
\hline Feeler & 11.538 & 3.306 & .917 & 1.308 & 63 & 2.021 & .200 \\
Thinker & 9.818 & 3.995 & .851 & & & \\
\hline
\end{tabular}


In sum, the results of analyses indicated that although the extroverts, sensates, and feelers outperformed the introverts, intuitives, and thinkers, the differences were not statistically significant.

\section{Discussion}

With regard to the role of cognitive learning styles, different studies have shown that some of these learning styles play a crucial role in learning a language, and so it is important for teachers to distinguish their learners' learning styles and prepare the teaching context based on their learners' style of learning (Reid, 1987; Celce-Murcia, 2001). Felder (1996) believes that what learners learn and how much they learn depend their ability, the prior experience, their learning style, and the teachers' teaching style. Moreover, some studies suggest that language learners will do better if the instruction and their learning style are aligned (Ehrman, 1996; Hartnett, 1985; Wesche, 1981).

Conventional instruction in Iranian English classrooms favors introverts (since they do not like to be the center of attention and like listening more than speaking), intuitives (since they pay attention to the relationships between things), and thinkers (since they think logically and are able to analyze things and make decisions based on the existing evidence). On the other hand, as stated earlier, the instruction applied in this study, i.e. explicit preemptive focus-on-form, let the students be active participants, reflect on their experience, produce something, and work in small groups. That is, in the first session they worked individually and paid attention to the underlined parts in order to elicit the rule and then in the next session they did a gap filing exercise and also had to complete some sentences. Therefore, they had the opportunity to consult with other members of the group and to make sentences that were socially acceptable. All the activities in the two sessions provided an opportunity for the participants to employ their different learning styles in the process of learning. The findings of the research indicated that the extroverts, sensates, and feelers students outperformed the introverts, intuitives, and thinkers. However, no statistically significant differences were found between these small groups with 3 students. Since they were in small groups, all member could benefit the instruction and no significant difference was observed between them.

The results of this study pointed out that generally extrovert learners performed better than introvert ones. According to Reid (1995), extroverts enjoy group work and introverts prefer working and studying individually. The study conducted by Mulalic, Mohd Shah, and Ahmad (2009) yielded similar results and showed that those who prefer group learning style outperformed the learners with individual learning style preferences. Moreover, the study carried out by Moenikia and Zahed-Babelan (2010) indicated that students with social learning style enjoyed a higher score in the structure section of a TOEFL and were significantly different from other students. Maybe the slightly better performance of the extroverts in the present study was because of the group work which was conducted in the classroom.

Sensate and intuitive learning styles posed by Reid (1995) are similar to what Felder and Silverman (1988) call sensing and intuitive. The former includes learners who are concrete thinkers and practical, whereas the latter refers to those considered as abstract thinkers and innovative. In this study, the instruction favored sensate students because they had to work to produce, in written form, and complete a sentence or complete a cloze passage. As the 
result revealed, although there was no significant difference between the two groups, the sensates outperformed the intuitives. This was in contrast with the findings of the studies conducted by Felder and Henriques (1995), Ehrman and Oxford (1995), Ehrman (1994), and Moody (1988). They demonstrated the language learning advantage of those enjoying intuitive style. However, Lalonde and Gardner (1984) found that there was a significant negative relationship between innovation (intuitive learners) and achievement.

With regard to feelers who performed a little better than thinkers in this study, it can be said that feelers are usually more empathetic and like meeting the needs of others and consider social values to a great extent. This feature is what Riazi and Riasati (2007) state in the conclusion of their study: Being able to use the language effectively in a real life situation made the learners feel satisfied with their achievement in English. Therefore, they had a tendency to group work to meet their own learning style needs, and use the language more effectively.

As mentioned before, the difference between the groups was not statistically significant which may be because of the fact that students were not at the extremes of the continuum in each pair. It is likely that in focus-on-form instruction nearly different needs of different personalities are considered so it can be suitable for both introverts and extroverts, etc. Of course the findings of this study is in line with the research conducted by Ehrman and Oxford (1995) demonstrating that second language learning and learning style are weakly related to each other.

\section{Conclusion}

The Paragon Learning Style Inventory and other learning style inventories can have two important applications in education. Firstly, they provide teachers with information about the diversity of learning styles among their learners and consequently, help them design the instruction capable of meeting the learners' needs. Thus, teachers can achieve balanced course instruction and help their students understand their strengths and weaknesses. Secondly, they give students insights into their potential learning strengths and weaknesses and help them work on the skills associated with their less preferred styles and not to be critical just of the approach the teacher is teaching. Therefore, they can get a better understanding and accept that sometimes they have the responsibility for the failures. Therefore, it is recommended that teachers apply a learning style inventory to know their students better and prepare the classroom instruction based on their learning styles. However, it should be mentioned that focus-on-form instruction can be successful almost for all the learning styles worked on in this study.

This study had some limitations including not having a control group. If there were a control group taught based on focus-on-forms, the results of this study would be more reliable. Moreover, it would be better to spend more time and teach more grammatical structures to assure that the changes in the performance were due to the type of instruction.

\section{Acknowledgements}

We would like to thank all the students who kindly took part in the study. 


\section{REFERENCES}

Barkhuizen, G.P. (1998). "Discovering learners' perceptions of ESL classroom teaching/learning activities in a South African context", in TESOL Quarterly, 32, 1: 85-108.

Celce-Marcia, M. (2001). Teaching English as a Second or Foreign Language (3rd ed.). NY: Dewey Publishing Services.

DeyKeyser, R., Salaberry, P., Robinson, P. and Harrington, M. (2002). "What gets processed in processing instruction? A commentary on Bill VanPatten's processing instruction: An update", in Language Learning. 52, 4: 805-824.

Dornyei, Z. and Skehan, P. (2005). "Individual differences in second language learning”, in C. J. Doughty and M. H. Long (eds.), The Handbook of Second Language Acquisition. United Kingdom: Blackwell Publishing, 256-310.

Doughty, C. J. (2001). "Cognitive underpinnings of focus on form”, in P. Robinson (ed.), Cognition and Second Language Instruction. Cambridge: Cambridge University Press, 206-25.

Doughty, C. J. (2005). "Instructed SLA: constraints, compensation, and enhancement", in C. J. Doughty and M. H. Long (eds.), The Handbook of Second Language Acquisition. Cambridge: Cambridge University Press, 256-310.

Doughty, C. J. and Varela, E. (1998). "Communicative focus on form”, in C. J. Doughty and M. H. Long (eds.), The Handbook of Second Language Acquisition. Cambridge: Cambridge University Press, 114-38.

Doughty, C. and Williams, J. (1998a). Focus on Form in Classroom Second Language Acquisition. Cambridge: Cambridge University Press.

Doughty, C. and Williams, J. (1998b). "Pedagogical choices in focus on form", in C. Doughty and J Williams (eds.), Focus on Form in Classroom Second Language Acquisition. Cambridge: Cambridge University Press, 197-262.

Ehrman, M.E. (1996). Understanding Second Language Learning Difficulties: Looking Beneath the Surface. Thousand Oaks, CA: Sage Publications.

Ehrman, M.E. (1994). "The type differentiation indicator and adult foreign language learning success", in Journal of Psychological Type, 30: 10-29.

Ehrman, M.E. and Oxford, R. (1995). "Cognition plus: correlates of language learning success", in Modern Language Journal, 79, 1: 67-89.

Ellis, R. (2001). "Introduction: investigating form-focused instruction", in Language Learning, $51,1: 1-46$.

Ellis, R., Basturkmen, H. and Loewen, S. (2001a). "Learner uptake in communicative ESL lessons", in Language Learning, 51, 2: 281-318.

Ellis, R., Basturkmen, H. and Loewen, S. (2001b). "Preemptive focus on form in the ESL classroom", in TESOL Quarterly, 35, 3: 407-32.

Ellis, R., Basturkmen, H. and Loewen, S. (2002). "Doing focus-on-form", in System, 30, 4: 419-32.

Felder, R. (1996). "Matters of style", in ASEE Prism, 6, 4: 18-23.

Felder, R.M. and Henriques, E.R. (1995). "Learning and teaching styles in foreign and second language education", in Foreign Language Annals, 28, 1: 21-31.

Felder, R. and Silverman, L. K. (1988). "Learning and teaching styles in engineering education", in Journal of Engineering Education, 78, 7: 674-81.

Fowler, W.S. and Coe, N. (1976). Nelson English Language Tests. Australia: Thomas Nelson Ltd.

Fotos, S. (1993). "Consciousness raising and noticing through focus on form: Grammar task performance versus formal instruction", in Applied Linguistics, 14, 4: 126-41. 
Fotos, S. (1994). "Integrating grammar instruction and communicative language use through grammar consciousness raising tasks", in TESOL Quarterly, 28, 3: 323-51.

Harley, B., Cummins, J., Swain, M. and Allen, P. (1990). "The nature of language proficiency", in B. Harley, P. Allen, J. Cummins, and M. Swain (eds.), The Development of Second Language Proficiency. Cambridge: Cambridge University Press, 7-25.

Hartnett, D. (1985). "Cognitive style and second language learning", in Celce-Murica, M. (ed.), Beyond Basics: Issues and Research on TESOL. Rowley, MA: Newbury House, 16-33.

Kavaliauskiene, G. (2003). "English for specific purposes: Learners' preferences and attitudes", in Journal of Language and Learning, 1, 1: 14-23.

Kolb, A. and kolb, D. (2005). The Kolb Learning Style Inventory - Version 3.1, 2005 Technical Specifications. Retrieved 15 November 2014 from www.whitewater-rescue.com/support/ pagepics/lsitechmanual.pdf.

Lalonde, R.N. and Gardner, R.C. (1984). "Investigating a causal model of second language acquisition. Where does personality fit?", in Canadian Journal of Behavioral Science, 16, 3: 224-37.

Leow, R. (1997). "Attention, awareness, and foreign language behavior", in Language Learning, 47, 3: 467-505.

Leow, R. (2002). "Models, attention, and awareness in SLA: A response to Simard and Wong's "Alertness, orientation, and detection: conceptualization of attention functions in SLA", in Studies in Second Language Acquisition, 24, 1: 113-19.

Long, M. (1991). "Focus on form: a design feature in language teaching methodology", in K. de Bot, R. Ginsberg, and C. Kramsch (eds.), Foreign Language Research in Cross-Cultural Perspective. Amsterdam: John Benjamins, 39-52.

Long, M. and Robinson, P. (1998). "Focus on form: theory, research and practice", in C. Doughty and J. Williams (eds.), Focus on Form in Classroom Language Acquisition. Cambridge: Cambridge University Press, 15-41.

Lyster, R. (2004). "Differential effects of prompts and recasts in form-focused instruction", in Studies in Second Language Acquisition, 26, 3: 399-432.

Lyster, R. and Mori, H. (2006). "Interactional feedback and instructional counterbalance", in Studies in Second Language Acquisition, 28, 2: 269-300.

Moenikia, M. and Zahed-Babelan, A. (2010). "The role of learning style in second language learning among distance education students", in Procedia Social and Behavioral Sciences, 2, 2: 1169-73.

Moody, R. (1988). "Personality preferences and foreign language learning", in Modern Language Journal, 72, 4: 389-401.

Mulalic, A., Mohd Shah, P. and Ahmad, F. (2009). "Perceptual learning styles of ESL students", in European Journal of Social Sciences, 7, 3: 101-13.

Nassaji, H. and Fotos, S. (2007). "Issues in form-focused instruction and teacher education", in S. Fotos and H. Nassaji (eds.), Form-Focused Instruction and Teacher Education. Oxford: Oxford University Press, 7-15.

Norris, J. and Ortega, L. (2000). "Effectiveness of L2 instruction: a research synthesis and quantitative meta-analysis", in Language Learning, 50, 3: 417-528.

Poole, A. (2005). "Focus on form instruction: Foundations, applications, and criticism", in The Reading Matrix, 5, 1: 47-56.

Reid, J. M. (1987). "The learning style preferences of ESL students", in TESOL Quarterly, 21, 1: $87-111$.

Reid, J. (1995). Learning Styles in the ESL/EFL Classroom. Boston, MA: Heinle and Heinle Publishers. 
Riazi, A. and Riasati, M. J. (2007). "Language learning style preferences: a student case study of Shiraz EFL institutes", in Asian EFL Journal, 9, 1: 97-125.

Robinson, P. (1995). "Attention, memory, and the noticing hypothesis", in Language Learning, 45, 2: 283-331.

Salimani, A. (1989). "The role of topicalization in classroom language learning", in System, 17, 2: $223-34$.

Schmidt, R. (1990). "The role of consciousness in second language learning", in Applied Linguistics, 11, 2: 129-59.

Schmidt, R. (1993). "Awareness and second language acquisition", in Annual Review of Applied Linguistics, 13: 206-226.

Sharwood Smith, M. (1981). "Consciousness-raising and second language acquisition theory", in Applied Linguistics, 2, 2: 159-68.

Sharwood Smith, M. (1993). "Input enhancement in instructed SLA: theoretical bases", in Studies in Second Language Acquisition, 15, 2: 165-79.

Swain, M. (2005). "The output hypothesis: theory and research", in E. Hinkel (ed.), Handbook of Research in Second Language Teaching and Learning. Mahwah, N. J: Lawrence Erlbaum Associates, 471-83

Swain, M. and Lapkin, S. (1995). "Problems in output and the cognitive processes they generate: A step towards second language learning", in Applied Linguistics, 16, 3: 371-91.

Tomlin, R. and Villa, V. (1994). "Attention in cognitive science and second language acquisition", in Studies in Second Language Acquisition, 16, 2: 183-203.

Wesche, M. (1981). "Language aptitude measures in streaming, matching students with methods and diagnosis of learning problems", in Diller, K. (ed.), Individual Differences and Universals in Language Learning Aptitude. Rowley, MA: Newbury House, 119-54.

White, J. (1998). "Getting the learners' attention: a typographical input enhancement study", in C. Doughty and J. Williams (eds.), Focus on Form in Classroom Language Acquisition. Cambridge: Cambridge University Press, 85-113.

Williams, J. (1999). "Learner-initiated attention to form", in Language Learning, 49, 1: 538-625.

Williams, J. and Evans, J. (1998). "What kind of focus and on which forms?", in C. Doughty and J. Williams (eds.), Focus on Form in Classroom Language Acquisition. Cambridge: Cambridge University Press, 139-55.

Wong, W. (2001). "Modality and attention to meaning and form in the input", in Studies in Second Language Acquisition, 23, 3: 345-68. 